INFORMAČNÉ TECHNOLÓGIE NA ZAČIATKU TRETIEHO MILÉNIA

(PIECUCH, A. Edukacja informatyczna na poczatku trzeciego tysiaclecia. 1. vyd. Rzeszów: Wydawnictwo Oświatowe FOSZE, 2008. 320 S. ISBN 978-83-7586-005-4).

\title{
Ján STEBILA
}

Publikácia Informačné technológie na začiatku tretieho milénia (Edukacja informatyczna na poczatku trzeciego tysiaclecia) sa pokúša analyzovat' obsah a učebné metódy na pol'ských školách $\mathrm{v}$ predmetoch zahrňujúcich informačné technológie. Publikácia je rozdelená do piatich kapitol. Prvá, Smerovanie vývoja elektronickej civilizácie (Kierunki rozwoju cywilizacji elektronicznej), prezentuje súčasné dimenzie informácií, ktoré sú uchovávané predovšetkým v elektronických prístrojoch. Zaoberá sa aj informačnými technológiami a ich konštruktívnou úlohou. Tiež poukazuje na rozličné možnosti použitia pokrokových informačných technológií v dnešnom svete, ako aj na ich využitie vo vzdelávaní i práci. Smeruje aj k civilizačným kompetenciám človeka, ktoré sú pre budovanie informačnej spoločnosti nevyhnutné. Druhá kapitola Vzdelávanie pre informačnú spoločnost' (Edukacja dla spoleczeństwa informacyjnego) prináša pohl'ad na vzdelávanie $v$ oblasti informačných technológií v Pol'sku v minulosti, súčasnosti i budúcnosti. Tretia kapitola Vzdelávanie s podporou počítača (Edukacja wspomagana komputerem) predstavuje pokus o pohl'ad na technologické možnosti použitia súčasných informačných technológií vo vzdelávaní. Prediskutované sú v nej hlavné body problematiky komunikácie a mediálnej výchovy. V tejto časti boli tiež rozvinuté záležitosti spojené priamo s použitím multimediálnych počítačov $\mathrm{v}$ didaktickom procese, ale aj typické vyučovanie a kvázi didaktický softvér. Je v nej i náčrt perspektívy on-line vzdelávania a úspechy v oblasti umelej inteligencie. Vo štvrtej kapitole Problémy učenia sa a vyučovania s podporou informačnokomunikačných technológii (Problémy uczenia sie i nauczania zwykorzystaniem Technologii Informacyjno-Komunikacyjnych) bola pozornost' venovaná záležitostiam vzájomnej interakcie človeka a počítača. Táto kapitola tiež zasahuje do psychologických aspektov učenia a vyučovania informačných technológií.

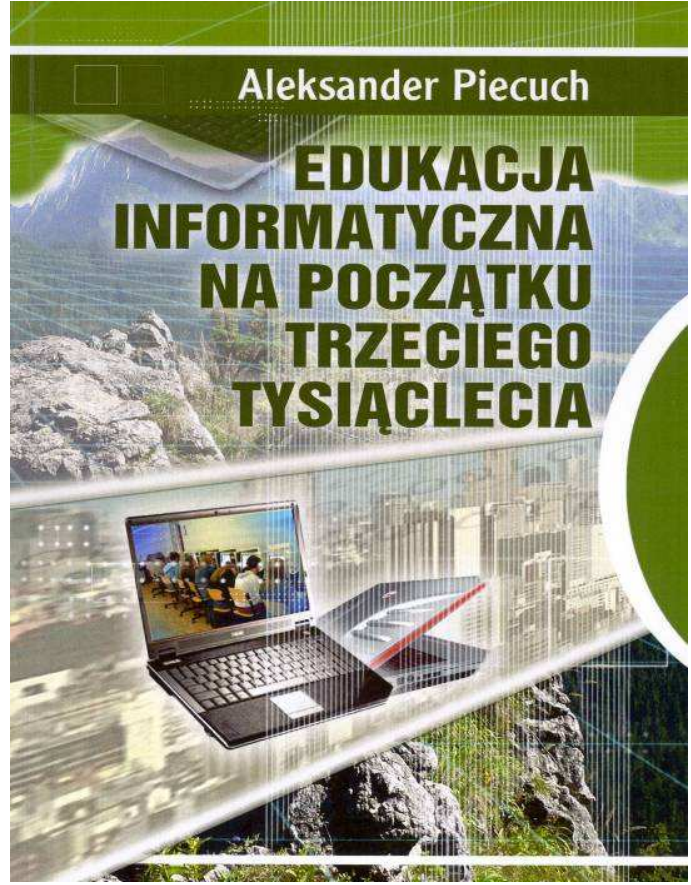

Plánovanie didaktického procesu pre predmety informačných technológií je považované za kl'účovú záležitost'. Prezentuje metódy plánovania s využitím didaktických máp. Pozornost' bola tiež venovaná nevyhnutným informačným kompetenciám žiaka a učitel'a. V tejto kapitole sú popísané multimediálne edukačné stratégie, organizácia vyučovania v triede a použitie projektových metód na rozvoj d'alších informačno-technologických kompetencií žiaka. Monografia končí piatou kapitolou, ktorá sa zaoberá Perspektívou vyučovania s informačno-technologickými zariadeniami (Perspektywy ksztalcenia wspomaganego środkami informatycznymi).

V závere môžeme konštatovat', že táto publikácia môže slúžit' nielen študentom, ale zároveň i učitel'om z praxe, ktorí hl'adajú inšpiráciu pre nové formy a metódy vo svojej práci. Publikácia je napísaná prehl'adne, doplnená zaujímavými ilustráciami a obrázkami. Má všetky predpoklady stat' sa dobrým zdrojom informácií $\mathrm{v}$ danej oblasti nielen v Pol'sku, ale i v zahraničí. 